\title{
Traces of the Other Form of Life
}

\author{
The Rural, the Urban, and Indonesians' Social Mobility \\ in Candra Aditya's Dewi pulang
}

\author{
Verena Meyer | ORCID: 0000-0001-5465-4833 \\ Columbia University, New York, NY, USA \\ vhm2111@columbia.edu
}

\begin{abstract}
Candra Aditya's short film Dewi pulang (2018) shows how Dewi's life in Jakarta is in tension with the life of her Javanese village, to which she returns when her father dies. Understanding Jakarta and the village as Wittgensteinean 'forms of life', I argue that the film portrays the two as simultaneously antagonistic and mutually intertwined, as each form of life is present in the other as a trace. The film uses the Javanese literary convention of sěmu, through which subtle messages are simultaneously revealed and concealed, to suggest that the transcendence of the conflict in the final scene defies reification through language because it seems impossible. By pointing to the reality of the unthinkable, the film proposes an understanding of incompatible forms of life and social locations as connected through complex interplays of presences and absences.
\end{abstract}

\section{Keywords}

absence - death - sěmu - social class - trace - Wittgenstein

\section{$1 \quad$ Introduction}

'Father is no longer here', Dewi says defiantly to her mother in a key moment of Candra Aditya's short film Dewi pulang (2018). She is spending several days in her family's house, having abruptly returned from her Jakartan life, job, and boyfriend upon learning about her father's sudden death. She is ready to go home, to Jakarta. 'Your father will still be in the house for forty days, child. Are you so heartless as to walk out on your father again?', retorts her mother 
(lines 89-9o). Different and mutually exclusive social relationships, languages, and temporalities appear to separate Dewi's life in Jakarta from her family's life in the Javanese village. Acceptance of one seems like a rejection of the other. In this essay, I want to think with the film through the dynamics that emerge when young, mobile Indonesians like Dewi navigate between such widely divergent social environments of which they are a part and which are, in some sense, a home for them. In the film, one of these is Dewi's rural Javanese home, a village organized around ritual and communal obligations; the other is Jakarta, where her and others' lives are structured by their jobs and their various 'modern', 'secular' pastimes and relationships.

I use the term 'form of life' for the organization or structure of these two cultural locations, a term I take from the work of Ludwig Wittgenstein who, somewhat obliquely, discussed forms of life in terms of '[w] hat has to be accepted, the given', thus pointing to the rules that define a range of possibilities of what it is in any specific situation to speak or act correctly and meaningfully (Wittgenstein 2009, PI II:238). Elsewhere, Wittgenstein elaborated that these rules are not universal or a priori but based on communal activity: "[I]t is characteristic of our language that the foundations on which it grows consist in steady forms of life, regular activity. Its function is determined above all by the action which it accompanies.' ${ }^{\text {T }}$ The term can thus be understood to underscore the interrelatedness of language on the one hand and practice or forms of social interaction on the other: forms of life are historically contingent and thus unstable. While forms of life are not necessarily self-contained, encounters with other forms of life are always accompanied by epistemic limitations: 'If a lion could talk, we could not understand him', Wittgenstein (2009, PI II:235) wrote, and sometimes an encounter between mother and daughter is no different. Dewi's Jakarta existence is not respected or valued by her mother, who understands her desire to return as a rejection of her father. Likewise, Dewi and her Jakarta friends express frustration and bemusement over their rural families and their expectations. On the surface, the film presents us with a binary that characterizes the life of many young Indonesians today: they move from their home towns to the cities, adopt urban forms of life and, even as they remain connected to their places of origin, become increasingly estranged from them.

But this simple binary is ultimately not accepted in the film, as its narrative brings to light a complex relationship between these different social locations. ${ }^{2}$

1 Wittgenstein 1976:404. I am using Glock's (1996:125) translation.

2 See Smith-Hefner 2019 for a nuanced discussion of the relations of urban youth culture with rural social life. 
As Dewi is moving between them, her rural Javanese and urban Jakarta forms of life are no longer separate but intertwined, even dependent on each other. Dewi's job in Jakarta provides her rural family with financial security, even prosperity. Meanwhile, the challenges and foibles of their families and rural lives provide Dewi and her Jakarta friends with the substance of their conversation (lines 1-38). Each place is haunted by the other. This haunted relationship comes to the fore when Dewi must negotiate in what ways her deceased father is present and absent, and what her obligations to him are. In the following, I will examine how the film depicts these complex relationships between and across different forms of life: how is the binary first constructed and then undercut? What kind of resolution of the tension between them do we see at the end? And how can we, with and beyond the film, conceptualize the presence and absence of each form of life in the other?

\section{Two Forms of Life}

The rural and the urban forms of life are set apart in the film through identity markers that become manifest in a variety of media. As Fox shows in this special issue, the use of distinct languages and code-switching is one of the ways in which these two dominant forms of life are marked as separate. In Jakarta, Dewi speaks Indonesian slang with her friends and English with her boss; in her parents' home, she speaks Javanese. The Indonesian slang connotes the Jakarta form of life's relaxed forms of social contact, while English indicates professionalism and cosmopolitanism. Javanese, on the other hand, marks the local and parochial, and with its multiple registers it indicates a social ethic of politeness and deference to elders. Distinct soundscapes are another marker of difference between these two forms of life. At the bar in Jakarta, we hear faint pop music in the background, pointing to the locale and its patrons' participation in a global entertainment culture; in rural Java, the soundscape is made up by Qur'anic recitation and calls to prayer, indicating the significance of ritual and participation in a certain normative piety.

As Dewi physically moves from one form of life to another, she is seen resisting adaptation to the rules governing her family's rural Java. Sometimes her resistance is very direct: the flip flops, for instance, that her mother wants her to wear in place of her sneakers remain unused until the very end, despite her mother's persistent nagging. At other times, Dewi seems to partially comply with the community's expectations but does so in a way that even this compliance turns into a moment of resistance. She covers her hair when she steps outside the house, but only perfunctorily, with much of her hair still showing. 
She is like a visitor to a foreign land who plays by the rules out of politeness while still making obvious that these are not her rules. What is more, the reason she left the house was to smoke, something quite inappropriate for a woman in this context, as becomes clear by her quick hiding of the incriminating cigarette as Bulik appears. Being questioned, she explains that she could not join the others at the graveyard because she has her period, an explanation of which Bulik appears sceptical and disapproves (lines 67-9).

And yet Dewi's lack of participation in her village's life, and her adaptation to life in Jakarta, cannot be seen as mere rejection but instead must be seen as a sort of ironic support, expressing a structural necessity in the relationship between these two forms of life. The film's intervention is not just to show that Dewi cannot choose one over the other, but that the possibility of her participation in the village form of life is complicated by a paradox: while Dewi's presence is demanded, her absence is required. ${ }^{3}$ Her mother may accuse Dewi of not loving her father when she voices her intention to go back to Jakarta before all death rites are completed; but it is nonetheless Dewi's leaving and absence that make these ceremonies, and other aspects of her family's form of life, possible in the first place. We learn in the course of the film that Dewi's income has financed the building and upkeep of the house (line 71). She also pays for the funerary rites which, we learn, total ID R 13 million, not yet including the cost of the goat (line 76). Dewi's resistance highlights one of the key points of antagonism driving the film. While her absence provides for her family's way of life, it also leaves her increasingly alienated from it.

Dewi's present absence in her home community can be conceptualized as, speaking now with Emmanuel Levinas, a 'trace', ${ }^{4}$ the presence of a being that is no longer present (Levinas 2006:38-44; Levy 1995). This absent being is different from non-being: it is something that leaves a mark, makes aware of its existence and absence, and thus becomes agentive in spite of its absence, or even because of it. Levinas differentiated between two different kinds of absences. The first is a momentary absence of something that exists in the world and

3 As noted above, the Jakarta form of life is also dependent on the rural form of life. Dewi and her friends share the experiences of village childhood and ongoing relations and obligations to their home communities and construct their Jakarta identity through its performative rejection.

4 The concept of the 'trace' has also been employed by other philosophers, including Derrida and Ricoeur. Here, I exclusively focus on Levinas's use of the term. 
can be expected to return. Such absences are represented by 'signs' and do not leave traces in Levinas's sense. Traces, in the second place, mark the absence of something that either has altogether ceased to exist or that cannot be present at all in the world because it is totally other. In Levinas's work, traces are what is left behind by a metaphysical other that is exterior to the subject and the subject's form of life and, hence, beyond 'being' or ontology. While it has a presence in this world, its presence points to its not being of this world. In Dewi pulang, it is not a transcendent otherness that is indicated by Dewi's trace: her absence, while no less total, is structural rather than metaphysical. By structural, I mean that her absence and her antagonistic urban form of life are required to sustain the structure of her home town's form of life. She must be absent from her home town and present elsewhere, in Jakarta, because her career is the condition of possibility for the sustainability of her family's life and rituals. A permanent return to her home town is structurally impossible. Even though she remains on the same metaphysical plane as her family, the structural necessity of her absence gives it the character of absence in Levinas's second sense: it is total rather than temporary.

Dewi's necessary absence, already paradoxical in itself, is further complicated by her mother's reactions. Even if the two forms of life are intertwined, they nonetheless are unintelligible and unjustifiable to each other. In their final confrontation mother and daughter find that, to use Wittgenstein's terms, they have exhausted the justifications, reached the bedrock, and their spades are turned (Wittgenstein 2009, PI: § 217). Dewi's absence and her ensuing estrangement may be the condition of possibility for her family's form of life, but the rituals she financially sustains through her absence also require her presence to be efficacious and socially acceptable. Her liminal position fuels the conflict between the mother, who wants Dewi to be more present, to stay longer, and to act more in agreement with her traditional form of life, and Dewi, who wants to leave and takes care to retain aspects of her Jakarta identity, resisting her mother's pressure to be more present.

When Dewi maintains that she needs to return to work after the seventhday commemoration of her father's death, she is confronted with her mother's insistence that she needs to stay as long as her father is still present in the house, until after the fortieth-day commemoration. Their conflict reaches its climax as the two discuss the ontological status and continued existence of her dead father. 'Father is no longer here', Dewi says (line 89), and her mother vehemently disagrees, accusing Dewi of not getting it, being heartless (line 9o), and of not loving her father (line 92). It is no coincidence that their fight escalates over the question of how to understand his present absence, as he is, along with Dewi, the second such present absence that pervades the film. 
During his lifetime, Dewi's father already seems to have had a mediating function between the two forms of life, representing an aspect of Dewi's rural home to which she and her friends can relate and even appreciate. In the bar, Dewi answers the phone when she thinks it is him calling, having previously ignored her mother's calls; and as she waits to break the news of her father's death to her friends, they comment on how he is 'cool' and 'friendly' (lines 301). His role as a mediator continues after his death through the traces his departure has left behind, especially during two key moments: the first of these is the above-mentioned phone call in the bar which occasions Dewi's going home to her family. Later in the film, Dewi receives a letter from her father which, as Paklik explains, he had intended to send before his death (line 94). Both phone call and letter are traces, the powerful presence of her father's absence that occasions Dewi's going home and that allows for a transcendence of the conflict in the final scene.

The traces left behind by Dewi's now absent father share another characteristic: their content, the actual message of both phone conversation and letter, is hidden. The audience never finds out but is left to guess who was on the phone with Dewi and what they said, and what her father wrote in the letter. We only see and hear Dewi's side, her short responses in krama, the refined or polite register of the Javanese language, to whoever called from her father's phone that yes, she will come home. And we see the outcome: Dewi goes home. Similarly, when Dewi reads her father's letter, all we see is her reaction, her tears, and the subsequent change in her behaviour, wearing the flip flops she had refused until then, sitting down in the kitchen with her mother, and helping her to grate coconut. By hiding what it was that caused these developments from the view of the audience, the film, rather than speaking directly, narrates the main turns of events by producing signs that simultaneously conceal and reveal meaning. This indirect way of conveying meaning is also known in other art forms in Java, especially Javanese poetry, a genre for which Florida, in her analysis of the nineteenth-century poem Babad Jaka Tingkir, made use of the Javanese term sěmu as an analytical category to characterize an elusive 'interplay between absence and presence' (Florida 1995:277). Sěmu, according to Florida, is 'a subtle sign' (p. 275) that points to the reality of something that is absent and hidden from direct perception or discursive knowledge. Indirect communication through sěmu is an aesthetic or ethical norm of speaking in a manner that is both beautiful and dignified. 
But the concept of sěmu goes further, as it does more than just optimally convey information: in the Babad Jaka Tingkir, sému as the interplay between absence and presence also participates in the production of new possibilities for the future. The poem narrating the origins of Islam in Java in the sixteenth century was written or inscribed in the mid nineteenth century from the vantage point of a Javanese king's exile to a Moluccan island at the hands of the Dutch colonial authority. Through sermu, the text continually points to the significance or contributions of those who, in standard histories written at the centres of royal power or Islamic learning, remain invisible: the wong cilik or underclass, on whom these centres of power depend to keep their political systems running, but whose contribution and significance is erased in historical writing because elite ideology has assigned them to a place of invisibility (Florida 1995:314). By pointing to the invisible or unspeakable, the poem constructs an alternative past that disrupts the inevitability of the present which, in its nineteenth-century context, was the colonial order. In its stead, it generates the framework for alternative futures in which the marginalized, erased, or exiled are able to be present and visible (Florida 1995:272).

By bringing Florida's concept of sěmu in conversation with Levinas's trace, we can develop a productive conceptual framework for thinking about the film. With Levinas, we can recognize the structural paradox of Dewi's position, her impossible status as someone who needs to break with a form of life and become an Other in order-from this position of total alterity-to provide the conditions of its existence. Florida's concept of sermu reveals the possibility of a transcendence of the conflict that results from Dewi's alterity and liminality. It breaks with the inevitability of the present by conceiving of, and creating a future in which conflict between mother and daughter is no longer the inevitable outcome of Dewi's paradoxical status. Put differently, if analysing Dewi in terms of Levinas's trace brings us to the irresolvable tension between the two forms of life she navigates and her inescapably liminal position in them, understanding her through the lens of sermu transcends this tension. But this transcendence is only possible because it is hidden from view. Since Dewi's Jakarta form of life paradoxically simultaneously enables and undercuts the traditional form of life, the liminality of her status is intrinsic or systemic. Consequently, her conflict with her mother cannot be resolved directly. The content of the letter is, in a sense, unthinkable, impossible. The film needs to resort to an indirect means of speaking about a transcendence of the problem, an interplay between absence and presence, as we see in her father's letter. His death and absence become present and agentive in the letter, through which Dewi is moved to seek a compromise with her mother. But this present absence is, itself, absent or concealed from the audience, who is 
left to guess what the content of the letter may have been. What the audience does see unfold, however, is the future that her father's present absence has generated: the transcendence of the conflict between the two seemingly opposing forms of life, and a compromise between mother and daughter over the joint grating of coconuts. Dewi will leave, but she will return for the fortiethday commemoration. After the conflict had escalated over the question of the status and presence of the dead, this transcendence of the conflict by means of the trace of her father's present absence does not take sides. Is her father still present or is he not? Has Dewi been right all along or has her mother? For the emergence of a future of compromise, both of these have to remain possible.

As Engchuan argues in this special issue, a short film is not self-contained but part of a larger relational process. Considering the film and the commentary it makes on different forms of life, and the relation between them as a node in a larger network, allows us to raise questions that point beyond what is seen on the screen, and especially to ask what kind of claim the film makes on us as academics when we try to describe Indonesians on the move. By resisting a reification of 'the traditional' and the 'modern', or the 'rural' and the 'urban middle class' as distinct stages in global temporal hierarchies (Chakrabarty 200o; Fabian 2014), does the film not also challenge notions of class or social location as stable and self-contained designators or containers for an audience of academics? Should anthropologists and sociologists not take seriously the film's subtle signs indicating that how this relation of dependence is made to work cannot even be pinned down, that it defies reification because it is hidden from view? Ultimately, all we see is that Dewi cannot be home in the village or in Jakarta, and that a transcendence of this impossible liminality can only be sěmu, as is, perhaps, the case with a whole generation of young Indonesians who can neither go nor stay.

\section{Acknowledgements}

I am grateful to Richard Fox for inviting me to join this discussion and thank him, along with Rosalia Engchuan and Thomas Barker, for their helpful feedback. I would also like to thank Daniel Esparza and Erez DeGolan, as well as the three anonymous reviewers, for their great comments on earlier versions 
of this paper. Finally, many thanks also to Candra Aditya for giving us the occasion to have this discussion by making the film Dewi pulang and for being a thoughtful conversation partner throughout the process.

\section{References}

Chakrabarti, Dipesh (2000). Provincializing Europe: Postcolonial thought and historical difference. Princeton: Princeton University Press.

Fabian, Johannes (2014). Time and the other: How anthropology makes its object. New York: Columbia University Press.

Florida, Nancy (1995). Writing the past, inscribing the future: History as prophecy in colonial Java. Durham: Duke University Press.

Glock, Hans-Johann (1996). A Wittgenstein dictionary. Oxford: Blackwell Publishers Inc. Levinas, Emmanuel (2006). Humanism of the other. Urbana: University of Illinois Press. Levy, Ze'ev (1995). 'On Emmanuel Levinas's concept of "trace" and "otherness" and their relationship to the thought of Jacques Derrida: A further contribution to URAM Levinas Studies (URAM 14:99-108)', Ultimate Reality and Meaning 18-4:289-302.

Smith-Hefner, N. (2019). Islamizing intimacies: Youth, sexuality, and gender in contemporary Indonesia. Honolulu: University of Hawai'i Press.

Wittgenstein, Ludwig (1976). 'Cause and effect: Intuitive awareness', Philosophia 6/3$: 409-25$.

Wittgenstein, Ludwig (2009). Philosophische Untersuchungen: Philosophical Investigations (PI). Oxford: Wiley Blackwell. 